\title{
Remodeling of extracellular matrix by normal and tumor-associated fibroblasts promotes cervical cancer progression
}

\author{
Alexandra Fullár ${ }^{1}$, József Dudás ${ }^{2}$, Lászlóné Oláh ${ }^{1}$, Péter Hollósi ${ }^{1,3}$, Zoltán Papp ${ }^{4}$, Gábor Sobel ${ }^{5}$, Katalin Karászi ${ }^{6}$,
} Sándor Paku ${ }^{1,3}$, Kornélia Baghy ${ }^{1}$ and Ilona Kovalszky ${ }^{1 *}$

\begin{abstract}
Background: Comparison of tissue microarray results of 29 cervical cancer and 27 normal cervix tissue samples using immunohistochemistry revealed considerable reorganization of the fibrillar stroma of these tumors. Preliminary densitometry analysis of laminin-1, a-smooth muscle actin (SMA) and fibronectin immunostaining demonstrated 3.8-fold upregulation of laminin-1 and 5.2-fold increase of SMA in the interstitial stroma, indicating that these proteins and the activated fibroblasts play important role in the pathogenesis of cervical cancer. In the present work we investigated the role of normal and tumor-associated fibroblasts.
\end{abstract}

Methods: In vitro models were used to throw light on the multifactorial process of tumor-stroma interaction, by means of studying the cooperation between tumor cells and fibroblasts. Fibroblasts from normal cervix and cervical cancers were grown either separately or in co-culture with CSCC7 cervical cancer cell line. Changes manifest in secreted glycoproteins, integrins and matrix metallo-proteases (MMPs) were explored.

Results: While normal fibroblasts produced components of interstitial matrix and TGF- $\beta 1$ that promoted cell proliferation, cancer-associated fibroblasts (CAFs) synthesized ample amounts of laminin-1. The following results support the significance of laminin-1 in the invasion of CSCC7 cells: 1.) Tumor-associated fibroblasts produced more laminin-1 and less components of fibrillar ECM than normal cells; 2.) The production of laminin chains was further increased when CSCC7 cells were grown in co-culture with fibroblasts; 3.) CSCC7 cells were capable of increasing their laminin production; 4.) Tumor cells predominantly expressed integrin a6 34 laminin receptors and migrated towards laminin. The integrin profile of both normal and tumor-associated fibroblasts was similar, expressing receptors for fibronectin, vitronectin and osteopontin. MMP-7 secreted by CSCC7 cells was upregulated by the presence of normal fibroblasts, whereas MMP-2 produced mainly by fibroblasts was activated in the presence of CSCC7 cells.

Conclusions: Our results indicate that in addition to degradation of the basement membrane, invasion of cervical cancer is accomplished by the remodeling of the interstitial stroma, which process includes decrease and partial replacement of fibronectin and collagens by a laminin-rich matrix.

Keywords: Cancer associated fibroblasts, Cervical cancer, Extracellular matrix remodeling, Integrins, Laminin-1, Stromal fibroblasts

\footnotetext{
* Correspondence: koval@korb1.sote.hu

${ }^{1}$ 1st Department of Pathology and Experimental Cancer Research,

Semmelweis University, Budapest, Hungary

Full list of author information is available at the end of the article
} 


\section{Background}

Tumor microenvironment has become the focus of intensive research as a potential target for cancer therapy [1]. In the normal epithelium, parenchymal cells and stromal components are physically separated by a basement membrane. The transition from normal epithelium to invasive carcinoma is preceded by, or is concomitant with, the activation of local host stroma [2]. Invasion occurs in close cooperation with stromal cells and the transformed epithelium [2,3]. Malignant progression impairs the integrity of the basement membrane resulting in the deterioration of its organized structure. Invasive tumor cells lose their epithelial characteristics and acquire metastatic phenotype. In this process a vast number of macromolecules are produced by stromal cells capable of influencing the microenvironment [4].

Fibroblasts are characteristic cell types in the microenvironment playing a prominent role in the pathology of solid tumors [5]. Cancer-associated fibroblasts (CAFs) within the reactive stroma express elevated amounts of extracellular matrix (ECM) proteins, proteases. These matrix metalloproteinases (MMPs) play an important role in the degradation of the basement membrane and stromal ECM initiating the invasion of malignant tumors $[6,7]$. During this process newly synthesized ECM proteins serve as a scaffold for motile tumor cells to move along, as well as providing structural support for angiogenesis [5].

To obtain invasive phenotype, cervical carcinoma cells may utilize stromal MMPs. MMP-7 and MMP-9 expressions can be induced in cancer cells, augmented by tumor-stromal cell interaction and possibly mediated by membrane-anchored and/or soluble factors [8]. Their expression has been shown to correlate with the amount of the hyaluronan (HA) receptor CD44 noted in low grade squamous cell carcinoma (SCC) $[9,10]$.

Growth signals generated by the stromal cells of the tumor are mediated to the cancer cells by integrins. These cell surface receptors are indispensable for the cross-talk between cancer cells and tumorous stroma [4,11]. Integrinmediated communication is pivotal in cell survival, proliferation, migration and tumor invasion [12].

In addition to thrombocytes, fibroblasts are the major sources of TGF- $\beta 1$, a cytokine that is one of the most important regulators of ECM. TGF- $\beta 1$ has a strategic role in the regulation of assembly and remodeling of extracellular matrix during cancer progression. Furthermore, the growth inhibitory action exerted by TGF- $\beta 1$ on epithelial cells disappears after malignant transformation, which together with the process of EMT, changes the status of the growth factor from inhibitor to tumor promoter [13]. The TGF- $\beta 1$ molecule is synthesized as an inactive multidomain complex and its activation occurs through multiple extracellular mechanisms that may involve proteases, thrombospondin-1 and integrins $[14,15]$. This implies that the interplay between tumor cells and fibroblasts can modulate the effect of growth factors that in turn exert their modified action on the tumor tissue $[4,16]$.

In the current work we investigated the course of matrix remodeling in cervical SCC by studying the molecular components listed above. To this end, we completed an immunohistochemical analysis of paraffin-embedded cervical SCC sections and established co-culture models between normal or tumorous cervical fibroblasts and CSCC7 HPV-positive cervix SCC cells.

\section{Methods}

\section{Tissues, cell lines and materials}

A tissue microarray (TMA) was generated from 27 normal and 29 cancerous, formalin fixed and paraffin embedded tissue blocks taken from the vaginal portions of cervices removed by radical Wertheim hysterectomy (Table 1). All cases had previously been analyzed for HPV genotypes [17]. Tissue blocks were collected from the $1^{\text {st }}$ Department of Obstetrics and Gynecology of Semmelweis University, with permission and seal from the Semmelweis University Regional and Institutional Committee of Science and Research Ethics (TUKEB permit number: 95/ 1999). Representative normal and tumorous areas on hematoxylin- and eosin-stained (HE) sections (identified by an independent pathologist) were excised. Tissue cores corresponding to the marked areas were used to assemble a TMA block which was then sliced, counterstained with hematoxilin and immunostained.

Fresh surgical specimens obtained from radical Wertheim hysterectomy were sent for routine pathology service to the $1^{\text {st }}$ Department of Pathology and Experimental Cancer Research from the Maternity Private Department of the Kútvölgyi Klinikal Block of Semmelweis University. Fibroblasts from normal and tumorous regions of uterine cervix not used for diagnosis were obtained from explant cultures. The surgical material was collected and used based on approval by the Semmelweis University Regional and Institutional Committee of Science and Research Ethics (TUKEB permit number: 95/1999). CSCC7 HPV16 positive cervical cancer cells, derived from a case of planocellular cervical cancer, were the gift of G. Gorter from Leiden University [18]. These cells exhibit a clear epithelial morphology and form nests when grown in monoculture. They are positive for pan-cytokeratin but negative for vimentin. In contrast, fibroblasts are vimentin positive, pan-cytokeratin negative cells displaying spindle-like morphology, with elongated, oval nuclei.

Materials and consumables used in cell cultures and the general chemicals used for the experiments were purchased from Sigma-Aldrich Co. (St. Louis, MO, USA), SARSTEDT AG\&Co (Nümbrecht, Germany) and Merck (Darmstadt, F. R. Germany). 
Table 1 Patient data to TMA

\begin{tabular}{|c|c|c|c|c|}
\hline Patient & Age & FIGO stage & Histology & HPV positivity \\
\hline 1 & 37 & $\| / A$ & Adenosquamous carcinoma & - \\
\hline 2 & 51 & I/B & Squamous cell carcinoma & - \\
\hline 3 & 42 & $\| / A$ & Squamous cell carcinoma & - \\
\hline 4 & 48 & $\| / B$ & Squamous cell carcinoma & HPV18 \\
\hline 5 & 39 & $\| / B$ & Squamous cell carcinoma & HPV 16, 18 \\
\hline 6 & 41 & $\| / A$ & Squamous cell carcinoma & HPV16 \\
\hline 7 & 38 & $\| / B$ & Squamous cell carcinoma & HPV16 \\
\hline 8 & 59 & $\| / B$ & Squamous cell carcinoma & HPV16 \\
\hline 9 & 39 & $\| / B$ & Squamous cell carcinoma & HPV16 \\
\hline 10 & 39 & I/B & Squamous cell carcinoma & HPV16 \\
\hline 11 & 71 & $\| / A$ & Clear cell carcinoma & HPV16 \\
\hline 12 & 51 & $\| / A$ & Squamous cell carcinoma & HPV16 \\
\hline 13 & 44 & $\| / B$ & Squamous cell carcinoma & HPV16 \\
\hline 14 & 42 & $\| / A$ & Squamous cell carcinoma & HPV16 \\
\hline 15 & 45 & $\| / B$ & Squamous cell carcinoma & HPV16 \\
\hline 16 & 32 & I/B & Squamous cell carcinoma & HPV16 \\
\hline 17 & 55 & $\| / B$ & Squamous cell carcinoma & - \\
\hline 18 & 56 & $\| / B$ & Squamous cell carcinoma & HPV16 \\
\hline 19 & 57 & $\| / B$ & Squamous cell carcinoma & HPV16 \\
\hline 20 & 44 & $\| / B$ & Squamous cell carcinoma & HPV16 \\
\hline 21 & 35 & I/B & Squamous cell carcinoma & HPV16 \\
\hline 22 & 66 & $\| / B$ & Squamous cell carcinoma & HPV16 \\
\hline 23 & 57 & $\| / A$ & Squamous cell carcinoma & HPV16 \\
\hline 24 & 38 & $\| / B$ & Squamous cell carcinoma & HPV16 \\
\hline 25 & 40 & $\| / B$ & Squamous cell carcinoma & HPV16 \\
\hline 26 & 52 & $\| / B$ & Squamous cell carcinoma & HPV16 \\
\hline 27 & 62 & $\| / B$ & Squamous cell carcinoma & HPV16 \\
\hline 28 & 57 & $\| / B$ & Squamous cell carcinoma & HPV16 \\
\hline 29 & 54 & $\| / B$ & Squamous cell carcinoma & HPV16 \\
\hline
\end{tabular}

Tissue microarray, histochemistry, immunohistochemistry and immunocytochemistry

TMA slides were immunostained for $\alpha$-smooth muscle actin (SMA), laminin-1, laminin-5 and fibronectin. Subsequently, they were scanned with a Scan Scope CS2 (Aperio Technologies Inc., Vista, CA, USA) and analyzed by MAN-0023 Color Deconvolution Algorithm Positive Pixel Count Analysis software (Aperio Technologies Inc.). Staining intensities were measured only in stromal areas, and percentage of positive and negative pixels were evaluated. Immunocyto- and immunohistochemistry procedures followed standard protocols [19]. Antibodies used are listed in Table 2. Cell nuclei were counterstained with TOTO-3 (Invitrogen by Life Technologies Co., Carlsbad, California, USA). Images were taken using MRC-1024 confocal laser scanning microscope (Bio-Rad Laboratories GmbH, Münich, Germany).

\section{Generation of cell cultures}

Tumorous and normal areas of surgical specimens taken from the same patient and not used for diagnosis were excised and cut into small pieces and placed into sixwell tissue culture dishes containing Cytogen Amnio Grow Plus medium (CytoGen GmbH, Sinn, Germany), optimized for development of primary cell culture. Fibroblasts were allowed to grow till the third passage and were then routinely transferred into DMEM-low glucose medium supplemented with $10 \%$ fetal bovine serum (FBS), $2 \mathrm{mM}$ L-glutamine, 100 units $/ \mathrm{mL}$ penicillin and $100 \mu \mathrm{g} / \mathrm{mL}$ streptomycin. Normal fibroblasts are hereinafter referred to as NF, fibroblasts derived from tumorous areas as TF. Purity of the fibroblast cultures was tested by means of vimentin and citokeratin immunostaining. On average, $<3 \%$ of epithelial contamination was found in the established fibroblast cultures. CSCC7 
Table 2 Antibodies used in the present study

\begin{tabular}{|c|c|c|c|c|c|}
\hline Primary antibodies & Host & Manufacturer* & Cat. no. & Dilution IHC/ IF & Dilution WB/DB \\
\hline$\beta$-Actin & Rabbit polycolnal lgG & Cell Signaling & 4967 & - & $1: 1000$ \\
\hline Laminin & Rabbit polycolnal lgG & Dako & Z0097 & $1: 200$ & - \\
\hline Laminin a1 $(\mathrm{H}-300)$ & Rabbit polycolnal lgG & Santa Cruz & sc-5582 & - & $1: 200$ \\
\hline Laminin $\beta 1(H-300)$ & Rabbit polycolnal lgG & Santa Cruz & sc-5583 & $1: 50$ & $1: 200$ \\
\hline Laminin 5 & Rabbit polycolnal lgG & Abcam & Ab14509 & $1: 100$ & - \\
\hline Laminin-5 (P3E4) & Mouse monoclonal lgG1 & Santa Cruz & sc-13587 & $1: 50$ & $1: 200$ \\
\hline Fibronectin & Rabbit polycolnal lgG & Dako & A0245 & 1:100 & - \\
\hline Fibronectin (IST-9) & Mouse monoclonal lgG1 & Santa Cruz & sc-59826 & $1: 40$ & $1: 500$ \\
\hline Smoth Muscle Actin colone 1A4 & Mouse monoclonal lgG1 & Dako & M0851 & $1: 200$ & - \\
\hline Thrombospondin 1 (A6.1) & Mouse monoclonal lgG1 & Santa Cruz & sc-59887 & - & $1: 250$ \\
\hline Perlecan & Mouse monoclonal lgG1 & Zymed & $13-4400$ & - & $1: 500$ \\
\hline Collagen I & Rabbit polycolnal lgG & Abcam & ab34710 & - & $1: 1000$ \\
\hline Collagen III & Rabbit polycolnal lgG & Abcam & Ab7778 & - & $1: 1000$ \\
\hline Anti-Human Collagen IV & Mouse monoclonal lgG1 & DakoCytomation & M 0785 & - & $1: 200$ \\
\hline Anti-Human MMP-7 & Mouse monoclonal lgG $\mathrm{l}_{1 \mathrm{~K}}$ & Chemicon & MAB3315 & - & $1: 500$ \\
\hline TIMP1 (D10E6) & Rabbit monoclonal lgG & Cell Signaling & 8946 & - & $1: 1000$ \\
\hline TIMP3 (D74B10) & Rabbit monoclonal lgG & Cell Signaling & 5673 & - & $1: 1000$ \\
\hline Integrin a4 & Rabbit polycolnal lgG & Cell Signaling & 4600 & - & $1: 1000$ \\
\hline Integrin a5 & Rabbit polycolnal lgG & Cell Signaling & 4705 & - & $1: 1000$ \\
\hline Integrin a6 & Rabbit polycolnal lgG & Cell Signaling & 3750 & - & $1: 750$ \\
\hline Integrin aV & Rabbit polycolnal lgG & Cell Signaling & 4711 & - & $1: 1000$ \\
\hline Integrin $\beta 1$ & Rabbit polycolnal lgG & Cell Signaling & 4706 & - & $1: 1000$ \\
\hline Integrin $\beta 3$ & Rabbit polycolnal lgG & Cell Signaling & 4702 & - & 1:100 \\
\hline Integrin $\beta 4$ & Rabbit polycolnal lgG & Cell Signaling & 4707 & - & $1: 1000$ \\
\hline CD44 & Mouse monoclonal lgG2a & Antibodies online & ABIN96695 & 1:100 & $1: 500$ \\
\hline CD151 (PETA-3) & Mouse monoclonal lgG2b & Novocastra $^{\text {TM }}$ Leica Biosystems & NCL-CD151 & $1: 50$ & - \\
\hline Secondary antibodies & Host & Manufacturer* & Cat. no. & Dilution IHC/IF & Dilution WB/DB \\
\hline Anti-mouse Ig/HRP & Goat polyclonal & DakoCytomation & P0447 & - & $1: 2000$ \\
\hline Anti-rabbit lg/HRP & Goat polyclonal & DakoCytomation & P0448 & - & $1: 2000$ \\
\hline $\begin{array}{l}\text { Alexa Fluor } 647 \text { anti-mouse } \\
\text { lgG }(\mathrm{H}+\mathrm{L})\end{array}$ & Donkey polyclonal & Invitrogen & A31571 & $1: 200$ & - \\
\hline $\begin{array}{l}\text { Alexa Fluor }{ }^{\oplus} 488 \text { anti-mouse } \\
\lg (H+L)\end{array}$ & Donkey polyclonal & Invitrogen & A21202 & 1:200 & - \\
\hline Alexa Fluor 647 anti-rabbit lgG $(H+L)$ & Goat polyclonal & Invitrogen & A21244 & $1: 200$ & - \\
\hline Alexa Fluor ${ }^{\circledR} 568$ anti-rabbit lgG $(H+L)$ & Goat polyclonal & Invitrogene & A11011 & $1: 200$ & - \\
\hline
\end{tabular}

*Cell Signaling Technology. Danvers. MA; DakoCytomation. Dako North America Inc. Carpinteria. CA. USA; Santa Cruz Biotechnology. Inc.. Santa Cruz. CA. USA; Zymed Laboratories Inc.. South San Francisco. CA. USA; Abcam plc. Cambridge. UK; Chemicon International Inc.. Temecula. CA. USA; Diagnostic BioSystems. Pleasanton. CA. USA; Antibodies-online Inc.. Atlanta. GA. USA; Leica Biosystems Newcastle Ltd. Newcastle. UK; Invitrogen by Life Technologies. Carlsbad. California. USA;

cells were routinely cultured in RPMI-1640 medium supplemented with 10\% FBS, $2 \mathrm{mM}$ L-glutamine, $1 \mathrm{mM}$ sodium pyruvate, 100 units $/ \mathrm{mL}$ penicillin and $100 \mu \mathrm{g} / \mathrm{mL}$ streptomycin. All cell lines were cultured in a humidified $95 \%$ air $/ 5 \% \mathrm{CO}_{2}$ incubator at $37^{\circ} \mathrm{C}$. The cell lines used were between the $8^{\text {th }}$ and $12^{\text {th }}$ passage, within which period both fibroblasts and CSCC7 cells proved to be stable.

\section{Co-culture systems}

Two models were used to study the interaction between fibroblasts and tumor cells. Direct co-cultivation allowed physical contact between cells, whereas in indirect cocultures cells were separated by a transwell insert with a $0.45 \mu \mathrm{m}$ pore size, allowing only molecular communication.

NF, TF, and CSCC7 cells were seeded in culture dishes $10 \mathrm{~cm}$ in diameter alone or in direct co-cultures with 
$5 \times 10^{5}$ cells/dish density in a 1:1 (v/v) mixture of DMEMlow glucose and RPMI-1640 supplemented with 5\% FBS. Seventy two hours after seeding, the FBS content was reduced to $0.3 \%$ and cells were incubated for $24 \mathrm{~h}$. Conditioned culture media (CCMs) and cell layers (CLs) were then harvested and frozen for further protein analyses. Samples from direct co-cultures are indicated as $\mathrm{NF}+$ CSCC7 and TF + CSCC7.

Indirect co-cultures were set up as follows: fibroblasts were seeded in 6-well plates (Corning Incorporated Life Sciences, Acton, MA, USA) at a density of $2.5 \times 10^{4}$ cells/ well in DMEM-low glucose with 10\% FBS. CSCC7 cells were placed in Transwell $^{\odot}$ polyester membrane inserts (Corning) with $0.45 \mu \mathrm{m}$ filter pore size at a density of $5 \times 10^{4}$ cells/insert in RPMI- 1640 with $10 \%$ FBS. Fortyeight hours after seeding CSCC7 containing inserts were placed in fibroblast containing wells followed by addition of 1:1 (v/v) mixture of DMEM-low glucose and RPMI1640 supplemented with 5\% FBS to the indirect coculture and to control cells growing alone. Seventy-two hours later the FBS content was reduced to $0.3 \%$ for another 24-h incubation period. CCMs and CLs were then collected and frozen for subsequent dot blot, gelatin zymography and ELISA assays. This treatment of the cells minimized the potential disturbing effects of serum metalloproteinases [20]. NF/CSCC7 and TF/CSCC7 indicate fibroblast samples isolated from the bottom of the filter compartment, whereas NF/CSCC7 and TF/CSCC7 designate tumor cell samples isolated from the inserts of indirect co-culturing plates.

\section{Proliferation assay}

The principles of sulforhodamine B (SRB) colorimetric assay were described earlier [21]. This protocol was used in the current study with the following modifications. Fibroblasts or CSCC7 cells were seeded in 96 well plates at densities of $2.5 \times 10^{3}$ or $3.5 \times 10^{3}$ cells/well in $200 \mu \mathrm{L}$ complete growth medium. All experimental conditions were run in 8 or 16 parallel samples. After counting, viable cells were let to seed and attach. Zero time point was considered three hours later after all cells were attached. SRB measurements were carried out at the time points of $0,24,48,72$ and $96 \mathrm{~h}$. Cells were originally grown in the presence of $5 \%$ FBS, but to observe the potential negative effects of serum starvation applied in the last $24 \mathrm{~h}$ of the co-culture experiments, the FBS concentration was decreased to $0.3 \% 24 \mathrm{~h}$ before harvesting the cells. To mimic the effects of co-cultivation on cell proliferation, fibroblasts were allowed to grow with CCM of tumor cells, and the latter with CCM of fibroblasts. Specifically, the culture medium contained $50 \%$ regular and $50 \%$ conditioned medium that was conditioned for $48 \mathrm{~h}$ and sterile filtered. The incubation mixture was replaced every $24 \mathrm{~h}$. To control these assays, cells were grown in
DMEM-low glucose and RPMI-1640 mixed in 1:1 (v/v) ratio and supplemented with 5\% FBS.

\section{Chemotaxis assay}

Chemotaxis assays were performed in Boyden chambers as previously described [21]. The following materials were used as chemoattractants in separate assays: tissue culture medium with $10 \%$ FBS, medium conditioned by the two types of fibroblasts (NF and TF), fibronectin (from human plasma, Sigma, $25 \mu \mathrm{g} / \mathrm{mL}$ ), and laminin-1 (from Engelbreth-Holm-Swarm murine sarcoma basement membrane, Sigma) diluted in serum-free medium to $25 \mu \mathrm{g} / \mathrm{mL}$. The cells were treated with $10 \mu \mathrm{g} / \mathrm{mL}$ mitomycin C (Sigma) for five minutes in order to inhibit proliferation [22]. Two days after mitomycin $\mathrm{C}$ treatment, $5 \times 10^{4}$ CSCC7 cells were seeded into the upper chambers of a 48-well Micro Chemotaxis Chamber (Neuro Probe, Gaithersburg, MD, USA) with medium containing $10 \%$ FBS and migration was allowed for $24 \mathrm{~h}$. Cell migration toward each chemoattractant was measured in triplicate samples. Migrated cells were stained with toluidine blue with 3 random fields per well. Accordingly, 9 random fields per each chemoattractant were counted.

\section{Protein expression and activity measurements Western and dot blot}

For Western blot, cells were grown as indicated above in the co-culture system. CCMs were collected and cells were extracted by lysis buffer containing $20 \mathrm{mM}$ HEPES $\mathrm{pH}$ 7.8, $10 \mathrm{mM} \mathrm{KCl}, 0.1 \mathrm{mM}$ EDTA, $1 \mathrm{mM}$ dithiothreitol, $1 \%(\mathrm{v} / \mathrm{v})$ Nonidet P40 and protease inhibitory cocktail, and then cells were homogenized. Protein concentrations were determined by the method of Bradford [23], using Ultroscpec-2000 UV/VIS Spectrophotometer (Hoefer Pharmacia Biotech Inc, San Francisco, CA, USA). Isolated proteins were run on Western blot or loaded onto dot blot as described previously $[19,24]$. An amount of $20 \mu \mathrm{L}$ of each sample was loaded per lane. Lysates from indirect co-cultures were quantified and $15 \mu \mathrm{g}$ total protein of each sample was loaded per lane. Western blot was normalized to $\beta$-actin. To prepare dot blots $200 \mu \mathrm{L}$ CCM per well was blotted onto a nylon membrane by Minifold-Vacuum-Filtration system SRC-96 (Schleicher\&Schuell, Dassel, W. Germany), then subjected to immunoassays. Results were normalized to Ponceau $S$ staining. Primary and secondary antibodies are listed in Table 2 .

\section{Caseinase and gelatinase zymogram analysis}

For caseinase and gelatinase zymogram analysis, $20 \mu \mathrm{L}$ CCM was used, and normal human serum as control $[19,25]$. Protease activities were visualized by Coomassie Blue staining (Bio-Rad Laboratories GmbH). Densitometry was carried out on a Kodak Image Station 4000MM 
Digital Imaging System using Kodak Molecular Imaging Software v. 4.0.3 (Eastman Kodak Company, Rochester, NY, USA).

\section{ELISA}

CXCL12/SDF-1 and TGF- $\beta 1$ levels were quantified in mono and co-cultures with the human CXCL12/SDF-1 $\alpha$ and TGF- $\beta 1$ ELISA Kit (R\&D Systems, Minneapolis, MN, USA) using $100 \mu \mathrm{L}$ CCM per sample. As the kit measures active TGF- $\beta 1$, latent TGF- $\beta$ complexes were activated before immunodetection as suggested by the manufacturer. ELISA plates were read at $570 \mathrm{~nm}$ with Labsystem Multiskan MS 352 (Labsystems, Finland) plate reader.

\section{Statistical analysis}

All experiments were performed in three independent sets, each containing at least three biological replicates. Relative gene expression results were tested for normal distribution by D'Agostino-Pearson omnibus test using GraphPad Prism 4.03 (GraphPad Software, Inc.). Significance of differences between co-culture vs. control values was evaluated by non-parametric tests (Mann-Whitney) and Student's $t$-tests depending on the distribution of data. Independent experimental sets were then compared for reproducibility. Only reproducible changes with a $\mathrm{p}<0.05$ level [20] were considered significant. Results of SRB measurements were evaluated by $\mathrm{X}^{2}$ test.

\section{Results}

\section{Changes in ECM structure of cervical cancer}

Figure $1 \mathrm{~A}$ and $\mathrm{B}$ shows the characteristic HE staining of normal (A) and tumorous (B) cervix in tissue microarray. SMA positivity was detected in the smooth muscle layer of blood vessel walls in normal subepithelial stroma (Figure 1C), whereas mainly stromal myofibroblasts displayed positivity in tumors (Figure 1D). The intensity of SMA immunostaining was 5.2-fold higher (Mann Whitney test: $\mathrm{p}<0.0001)$ in cervical cancer than in normal tissues (Figure 2). Laminin-1 could be detected in the basement membranes underlying epithelial cells and in the blood vessels in the normal stroma (Figure 1E). In addition to being localized to the same compartments, laminin-1 was deposited in the tumorous interstitial stroma. Incomplete laminin-1 positive basement membrane was seen around the leading edges of tumorous nests (Figure 1F). Compared to normal tissue, laminin-1 protein expression showed a 3.8-fold increase (Mann Whitney test: $\mathrm{p}<0.0001$ ) in the tumorous stroma (Figure 2). Laminin-5 was detected in the basement membrane of normal tissues (Figure 1G), while being present in the tumorous area only at the interface of tumor nests and stroma. At the periphery of tumor nests, the cytoplasm of cancer cells was loaded with laminin-5 (Figure $1 \mathrm{H}$ ).
Due to the lack of extensive stromal immunostaining laminin-5 was not evaluated by the software used for other proteins. Fibronectin was evenly and abundantly distributed both in the normal (Figure 1I), as well as in the tumorous stroma with a minor 1.2-fold increase in the cancerous environment (Figures 1J and 2).

\section{Characteristics of normal and tumorous fibroblasts in tissue cultures Proliferation}

The proliferation rate of cells was measured under mono- and co-culturing conditions. When plating them together, fibroblasts surrounded the nests of tumor cells forming a structure that resembled the architecture seen in the tumor tissue. Fibroblasts grew in size and formed spaces between CSCC7 cells (Figure 3A). NF cells exhibited higher proliferation rates than TF fibroblasts. The proliferation of neither normal nor tumorous fibroblasts was stimulated by the conditioned media of cancer cells (Figure 3B-C).

\section{Secreted matrix protein profiles}

Quantitative changes in 11 matrix and secreted proteins were determined by dot blot from the culture media of cells growing alone and in direct or in indirect co-cultures (Figure 4). As a general phenomenon, TFs produced more laminin- $\alpha 1,-\beta 1$ and perlecan and less laminin-5, fibronectin, type III collagen and TIMP-1 than NFs (Figure 4A).

Direct contact between fibroblast and CSCC7 cells The presence of cancer cells resulted in about a twofold increase in laminin- $\alpha 1$ and - $\beta 1$ both in normal and tumorous fibroblast preparations (Figure $4 \mathrm{~B}$ versus Figure 4A). The amount of the two laminin chains was significantly higher in TF + CSCC7 as compared with NF + CSCC7 coculture, and this was true for perlecan as well (Mann Whitney test: $\mathrm{p}<0.001)$. On the contrary, type IV collagen was low in both co-cultures. Interestingly, TSP-1 production of fibroblasts was equal in both sets of samples. In comparison with the medium of NF alone (Figure 4A), the amount of collagens and fibronectin decreased in $\mathrm{NF}+$ CSCC7 co-culture, although still being higher than as measured in TF + CSCC7 co-culture (Figure 4B).

Indirect contact between fibroblast and $\mathrm{CSCC} 7$ cells In the event NFs and TFs had no physical contact with tumor cells but their media could communicate, no stimulatory effect was observed regarding the laminin chains. Furthermore, TFs secreted less laminin chains than NFs. The levels of fibronectin and fibrillar collagens did not differ significantly from those of control fibroblasts (Figure 4A,C). This observation clearly shows that fibroblasts do not produce MMP7. 


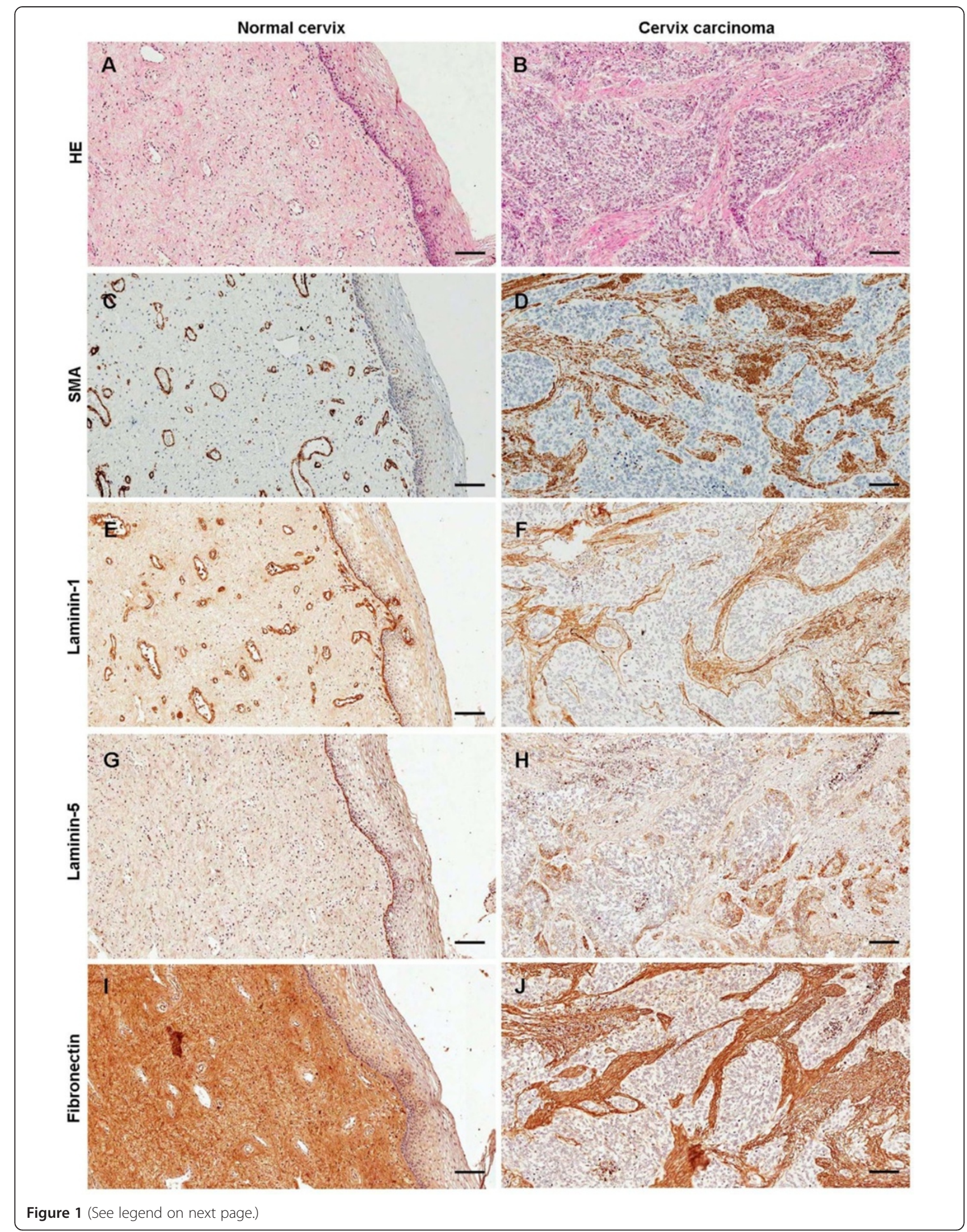


(See figure on previous page.)

Figure 1 Immunohistochemistry of ECM proteins in the normal cervix and in cervical cancer: H\&E staining (A, B). Smooth muscle actin reaction is detectable in the smooth muscle layer of small blood vessels in the normal subepithelial stoma (C), or the activated myofibroblasts in the stroma of cervical cancer (D). In the normal tissue laminin-1 is confined to the basement membrane of epithelial layer and small blood vessels (E), whereas in the tumor tissue multiple layers are formed around the tumor nests, filling up the stromal regions (F). Laminin-5 is present exclusively in the basement membrane of normal epithelium as a single layer $(\mathbf{G})$, whereas except for some abortive basement membrane-like formations, the immunopositivity resides in the cytoplasm of tumor cells $\mathbf{( H )}$. Fibronectin appears as homogenous staining in the connective tissue of normal cervix (I), the reaction is distributed in the tumorous stroma in a similar manner $(\mathbf{J})$. Scale bars $100 \mu \mathrm{m}$.

CXCL12/SDF-1 and TGF- $\beta 1$ secretion Concentrations of CXCL12/SDF-1 and TGF- $\beta 1$ were measured from culture supernatants by means of ELISA. No CXCL12/ SDF-1 could be detected in any of our experimental systems. Surprisingly, fibroblasts did not secrete TGF- $\beta 1$.

\section{Activity of matrix remodeling enzymes}

Positive MMP-1, MMP-2 and MMP-7 enzyme activities were found by casein and gelatin zymography of cell culture supernatants of direct (Figure 5A) and indirect (Figure 5B-D) co-cultures. Only fibroblasts exerted proMMP-1 activity, which was higher in TFs than in NFs. The pro-MMP-1 activity was reduced in the presence of CSCC7 cells (Figure 5A-B). MMP-2 was present both in its active and inactive forms (Figure 5A and 5C-D). CSCC7 cells in direct co-culture enhanced and activated MMP-2 in the medium of both types of fibroblasts (Figure 5A). However, in indirect co-culture CSCC7 cells did not affect the activity of the enzyme (Figure 5C-D).

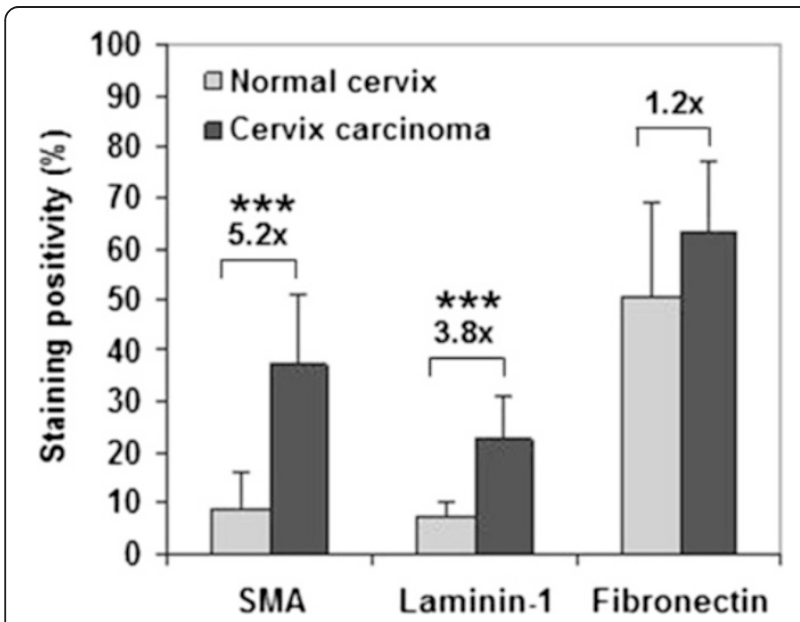

Figure 2 Densitometric evaluation of SMA, laminin and fibronectin of 27 normal and 29 tumorous specimens of tissue microarray. In the tumors the average intensity of SMA immunostaining was 5.2-fold higher, laminin-1 protein expression showed a 3.8-fold increase and fibronectin reaction was similar, showing a nonsignificant 1.2-fold increase in cervical cancer tissues (black column) as compared with normal (gray column) tissues. The signal positivity is shown as a proportion of the total measured area. Stars indicate significance: ${ }^{* *} p<0.001$.

\section{Expression of ECM binding membrane proteins and receptors} Integrin expressions in direct (Figure 6A) and indirect (Figure 6B) co-cultures were examined by immunoblot. Signals were normalized to those of $\beta$-actin. Integrins $\alpha 4$ and $\alpha 5$ were expressed exclusively by fibroblasts, whereas integrins $\alpha v, \beta 1$ and $\beta 3$ by both cell types (Figure 6 ).

On the whole, in case of TFs integrin expression was higher than in case of NFs. With the exception of integrin $\beta 1$, direct contact with tumor cells resulted higher levels of integrin expression in both NFs and TFs. Expressions of $\alpha \mathrm{v}$ and $\beta 3$ integrins were upregulated in co-cultures indicating the importance of this integrin pair in the cooperation between fibroblasts and tumor cells (Figure 6A). Indirect contact was capable of stimulating integrin expression in case of NFs, whereas TFs became unresponsive (Figure 6B).

Despite Figure 7 showing that both NFs and TFs expressed comparable amounts of CD44 on their cell surface, dot blots demonstrated the shedding activity of this cell surface glycoprotein in case of both fibroblasts. This activity was found to be much higher in case of NFs than in case of TFs, either alone or growing in direct and indirect co-culture (Figure 4).

The surface protein CD151 was equally positive on fibroblasts and tumor cells as indicated by immunostaining (Figure 7).

\section{Response of tumor cells to the presence of fibroblasts Proliferation}

Figure 3A illustrates that $48 \mathrm{~h}$ after seeding CSCC7 cells growing in direct co-culture contained a significantly larger amount of tumor cells than those growing alone and formed nests that were surrounded by normal fibroblasts. Compared to fibroblasts, their proliferation rate was higher and showed further increase when exposed to CCM of NF cells for 96 h (Student's $t$-test: $\mathrm{p}<0.0001$ ) (Figure $3 \mathrm{~B}$ ). The CCM of TF cells did not exert the same effect (Figure 3C).

\section{Secreted matrix protein profiles}

According to our results, CSCC7 cells synthesized laminin- $\alpha 1,-\beta 1,-5$, perlecan, TSP-1, CD44, MMP-7 and TIMP-1 (Figure 4A). When growing in direct co-culture with NFs, these cells strongly upregulated MMP-7 production (Figure 4B). Even in spatial separation, the co- 


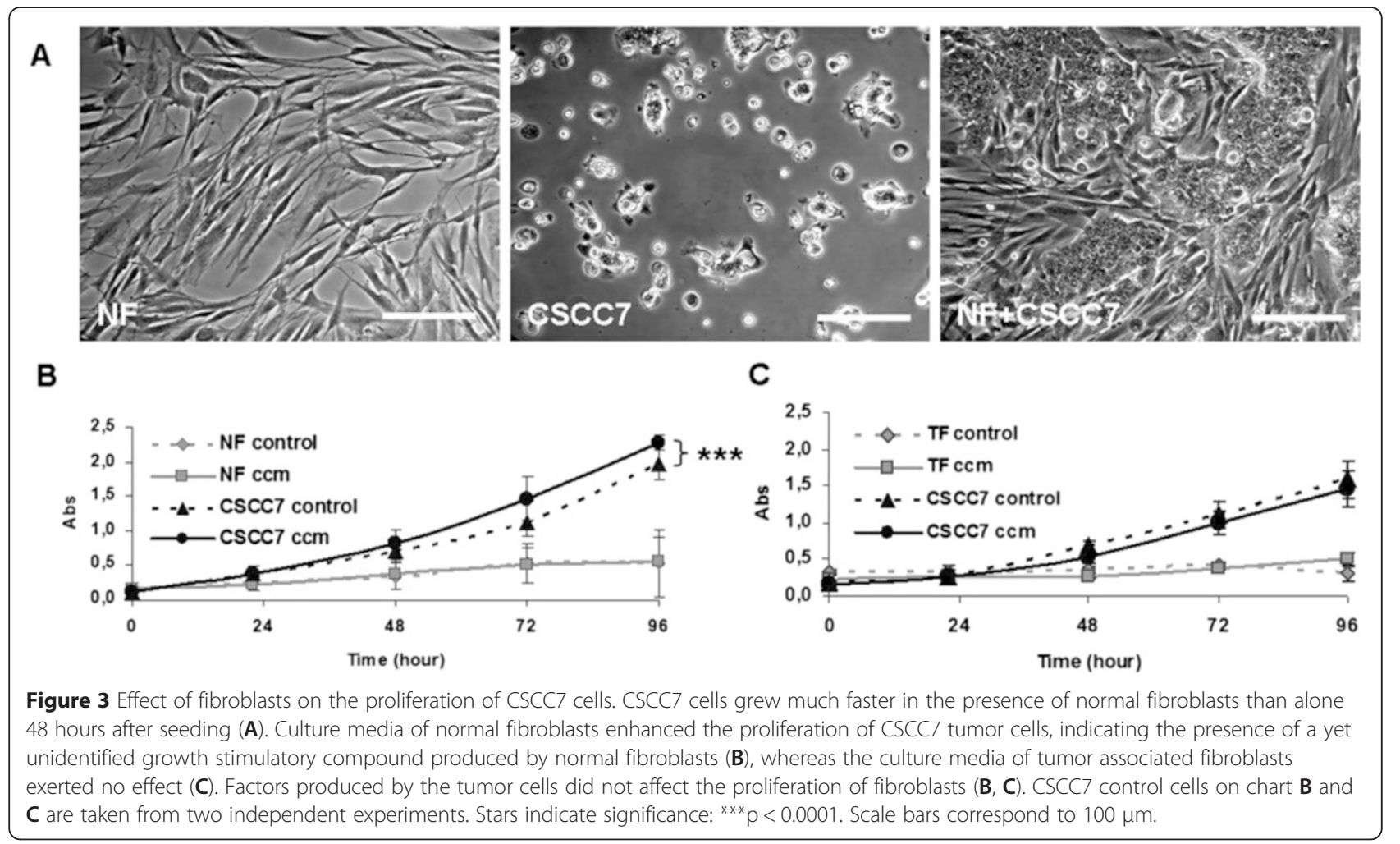

culture with fibroblasts seemed to induce the synthesis of laminin-1 by cancer cells (Figure 4D). The lack of laminin-5 in the medium was in agreement with the immunostaining shown in Figure $1 \mathrm{H}$ displaying the protein inside the cytoplasm of tumor cells.

Under all conditions, including monoculture, directand indirect co-culture, CCMs of CSCC7 cells contained active TGF- $\beta 1(\sim 50 \mathrm{pg} / \mathrm{mL})$. Physical contact with NFs, but not with TFs significantly increased the level of active TGF- $\beta 1$ (3.63-fold, Mann Whitney test: $\mathrm{p}<0.0001$ ), in case of the NF + CSCC7 medium (Figure 8).

\section{Activity of matrix remodeling enzymes}

The levels of protein expression and activity of MMP-7 were quantified (Figure 5). According to both measures, MMP-7 was produced only by CSCC7 cells. In direct co-culture, pro-MMP-7 activity and protein production were enhanced only in the presence of NFs (Figure 5A). Neither MMP2 nor MMP-9 activity was detected in tumor cells (Figure 5A and 5C-D).

\section{Expression of ECM binding membrane proteins and receptors} Integrins $\alpha 6$ and $\beta 4$ were found exclusively on tumor cells. Integrins $\alpha \mathrm{v}, \beta 1$ and $\beta 3$ were present both on fibroblasts and tumor cells (Figure 6). The presence of TF cells stimulated the expressions of integrin $\alpha 6$ and $\beta 4$ as well as integrin $\alpha \mathrm{v}, \beta 1$ and $\beta 3$ (Figure 6B).
In addition to integrins, the standard form of CD44, another ECM binding receptor, was able to form a complex with MMP-7 as detected by immunocytochemistry. As also shown by immunohistochemistry (Figure 7), tumor cells expressed ample amounts of CD44 on their surface. CD44 was found to be shed actively into the medium as a result of co-culture with NFs (Figure 4D).

The immunocytochemical staining of the integrin stabilizing cell surface protein CD151 is shown in Figure 7. Strong staining was detected between tightly packed CSCC7 cells in tumor nests, which faded on the surface of scattered tumor cells separated by TF cells in direct co-culture.

\section{Invasion and migration}

In addition to fibroblasts, tumor cells were found to adhere and start to proliferate in the primary cell cultures established from tissue explants. Since a prerequisite for tumor cell survival and growth is the prior lawn formation of fibroblasts, the tumor cells in these cultures were easily distinguishable from other cells owing to the fact that immune cells do not survive cultivation, so they could be excluded. Benign cells, like fibroblasts do not grow on top of each other, this is a characteristic feature of malignant cells. The morphological finding of cells spreading on the fibroblast lawn clearly corresponded to cancer cells by reason of their variable sizes and irregular features, large nuclei, prominent nucleoli, decreased 


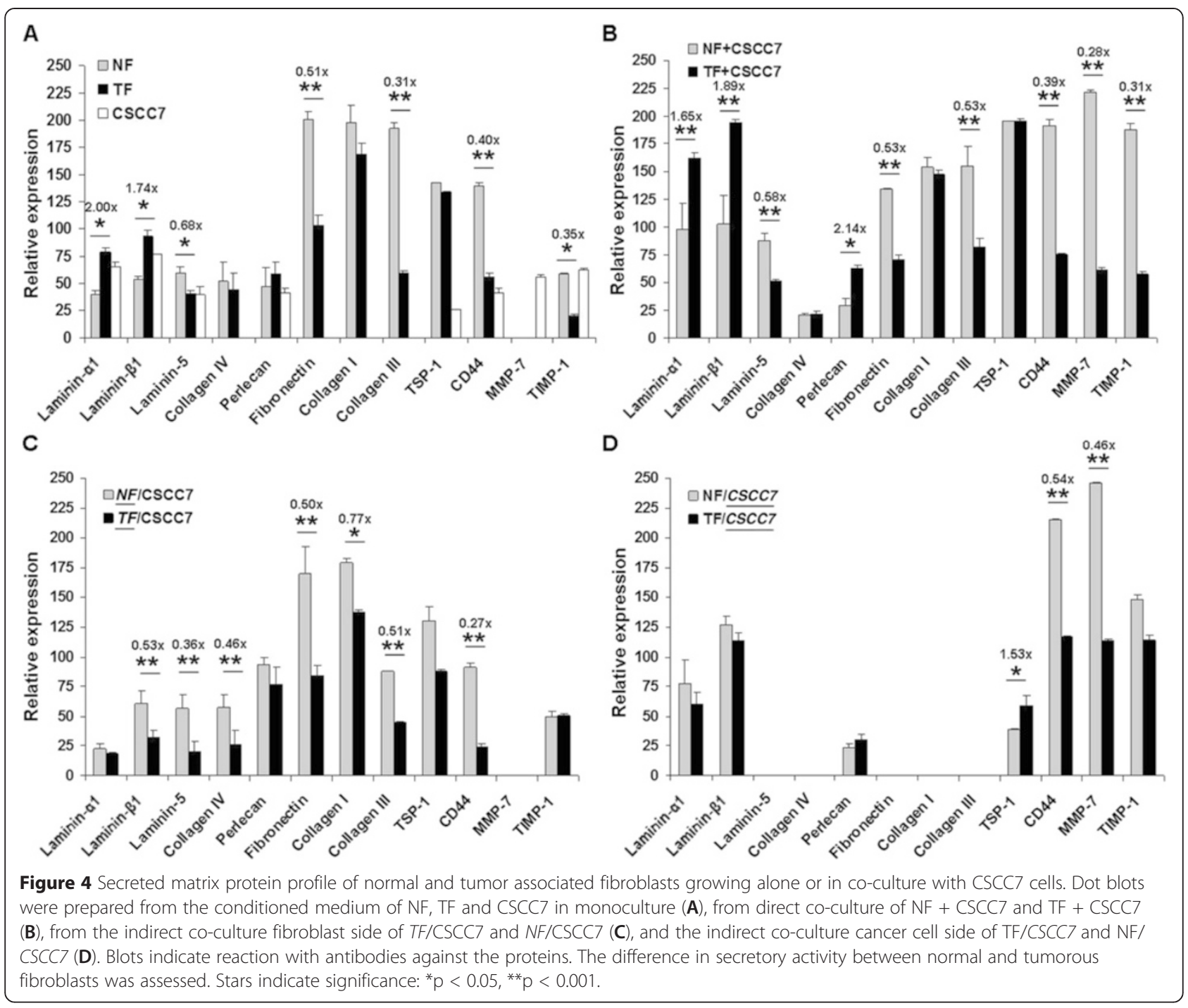

cytoplasm/nucleus ratio all of which are the criteria of malignancy. In addition, vimentin and pan-cytokeratin staining served to differentiate between cell types, corroborating our morphological observations, which imply that the presence of tumor-associated fibroblasts is a fundamental requirement for the growth of tumor cells. Instead of node formation, single tumor cells were seen to spread and migrate on top of the fibroblast layer (Figure 9A). A similar phenomenon was observed when CSCC7 cells were seeded on top of a confluent sheet of tumorous fibroblasts, inhibited by mitomycin $\mathrm{C}$ to grow. In these cases tumor cells failed to form groups, preferring rather to dwell and migrate in the form of single cells (Figure 9B).

To identify the most potent chemoattractant for tumor cell migration, mitomycin $\mathrm{C}$ treated $\mathrm{CSCC} 7$ cells were allowed to migrate toward various chemoattractants in a Boyden chamber for $24 \mathrm{~h}$. The medium, conditioned by co-cultured cells, attracted tumor cell migration very inefficiently. Laminin-1 proved to be the strongest chemoattractant, as the number of tumor cells migrating towards laminin- 1 increased by 2.7 -fold as compared with fibronectin (Mann Whitney test: $\mathrm{p}<0.0001$ ) (Figure 9C).

\section{Discussion}

The tumor microenvironment plays a pivotal role in the behavior of cancer [26]. To identify the characteristic changes of ECM as a result of tumor-matrix interactions we established a tissue microarray from cervical cancer specimens. One of the most striking changes noticeable after cancerous transformation was the upregulation and redistribution of laminin-1, depositing not only into basement membranes, but also into the fibrillar connective tissue. In line with this observation, SMA revealed strong stromal positivity, indicating the presence of activated 


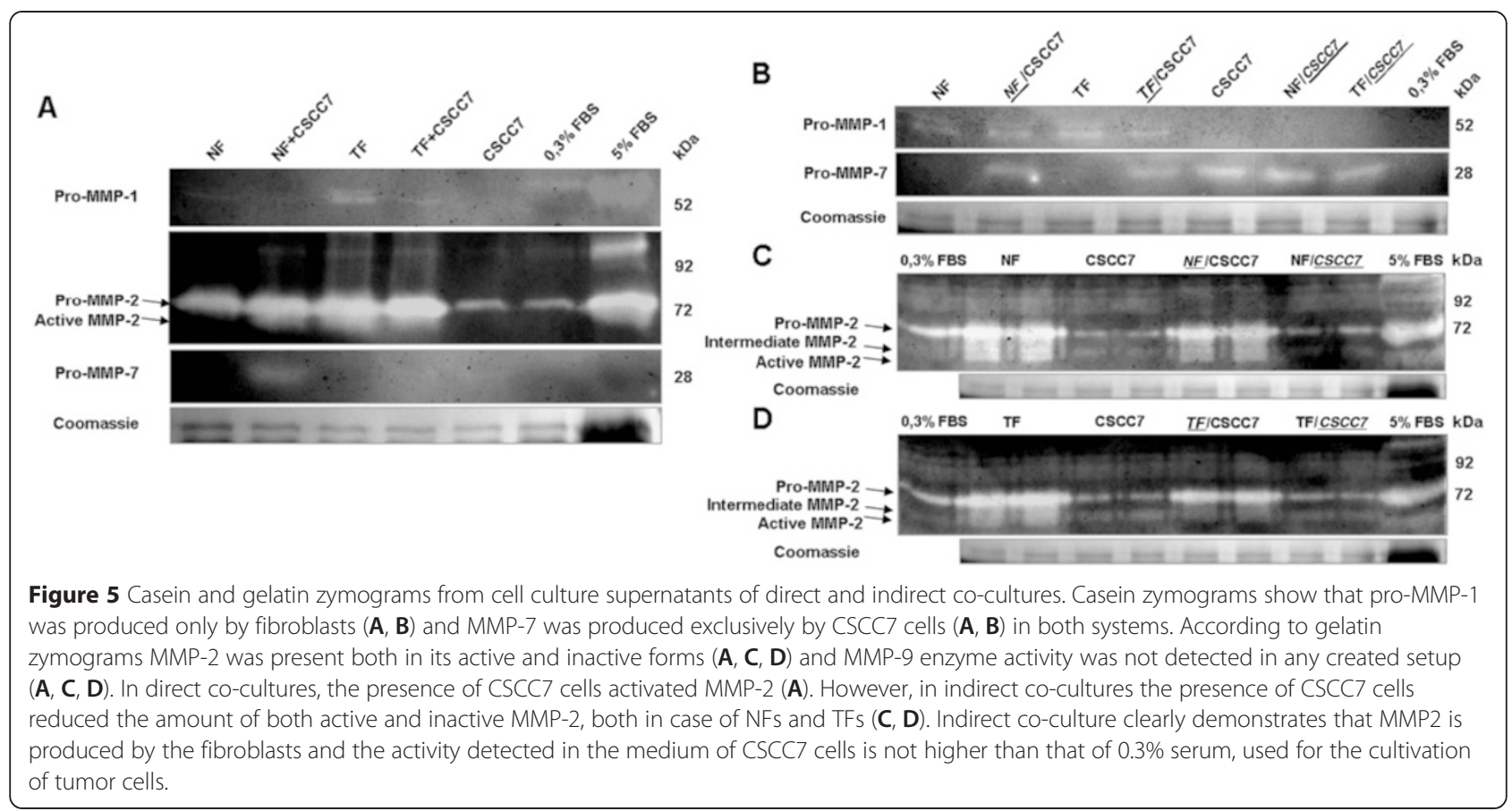

myofibroblasts that are the major producers of ECM in the stroma [27]. In support of earlier findings, laminin5 resided in the cytoplasm of cancer cells [28].

To obtain more information about the functions shared between fibroblasts and tumor cells, we established fibroblast cultures from tumor free cervix (normal fibroblasts) and tumorous parts of surgically removed cancerous uterine cervix (considered as tumor-associated fibroblasts). An established HPV16 positive cervical cancer cell line, CSCC7, served as the tumorous variance [18].

When grown alone, comparison of NF and TF cells showed NFs to predominantly synthesize components of the interstitial matrix, such as fibronectin and type I and III collagens. When placed into direct co-culture, only NFs were able to stimulate cancer cells to produce TGF$\beta 1$ and MMP-7, factors needed for proliferation and local invasion [5]. The conditioned medium of NFs but not TFs was capable of stimulating the proliferation of tumor cells.

Compared to NFs, TFs were reprogrammed to produce increased amounts of laminin- $\alpha 1$ and $-\beta 1$. These are components of laminin-111 known to be implicated in cancer progression, which contain peptide sequences active in proliferation, angiogenesis and metastasis [29].

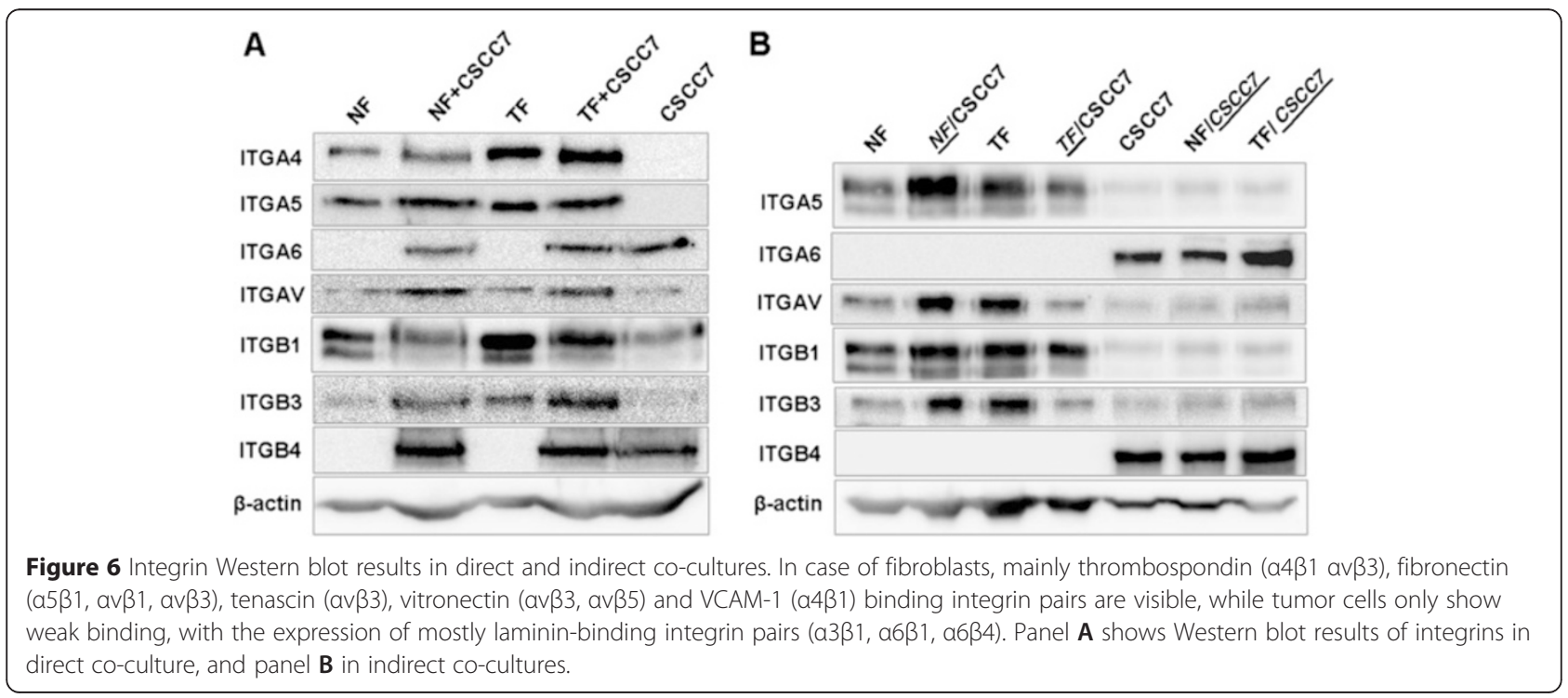




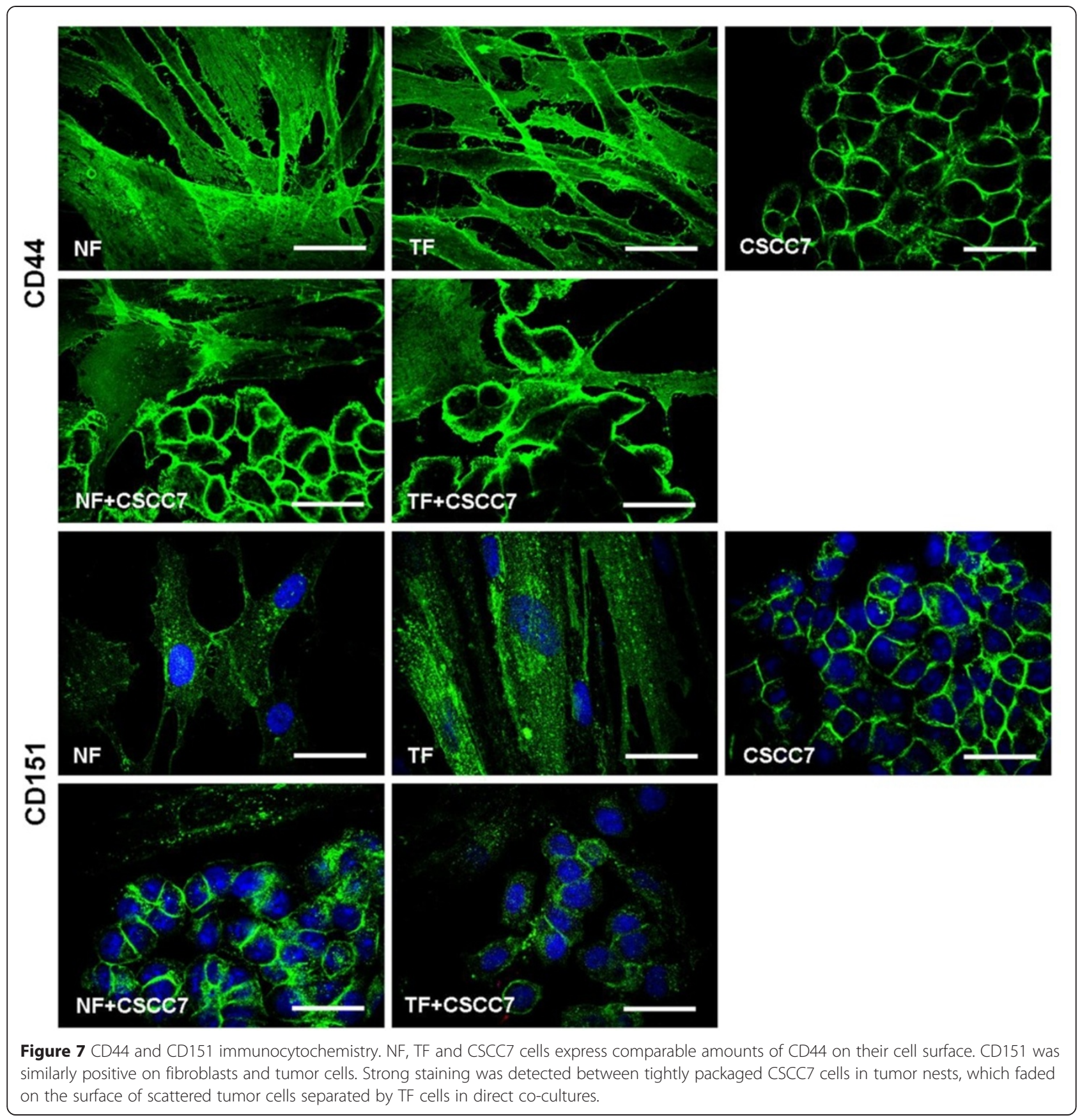

Furthermore, TF synthesized a smaller amount of type IV collagen, a protein which is prerequisite for the formation of natural basement membranes. The secretion of fibrillar matrix components was found to be decreased.

Direct co-culture of tumor cells with TFs resulted in the further increase of laminin-1 and perlecan and a decrease in type IV collagen secretion. Thus, it appears that cervical cancer cells are in need of a laminin-rich fibrillar matrix for their invasion, creating an imbalance between components of basement membrane molecules. The fact that laminin- $\alpha 1$ and $-\beta 1$ production stayed low when TFs were growing in indirect co-culture indicates that direct contact with tumor cells is needed for the enhancement of laminin synthesis. On the contrary, tumor cells were found to be capable of maintaining high laminin synthesis under such conditions, compensating for the low production of fibroblasts.

The importance of laminin-111 in the pathology of cervical cancer was underlined by the facts that laminin proved to be the most efficient chemoattractant in the Boyden chamber migration assay and that it was also produced by CSCC7 cells. These cells predominantly 


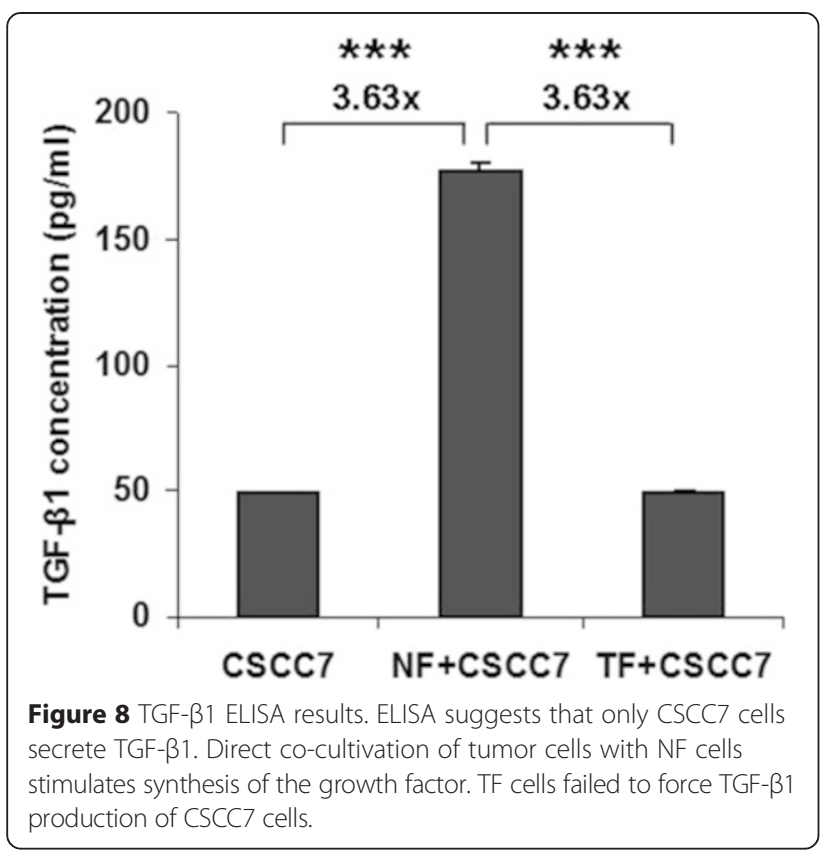

expressed $\alpha 6 \beta 4$ and $\alpha 6 \beta 1$ integrins, two laminin binding receptors [30]. This observation implied that lamininintegrin interaction took place both in paracrine and autocrine fashion. In addition to laminin-111, tumor cells growing alone secreted laminin-5, perlecan, MMP7, TIMP-1 and CD44. Although the current assay was limited to immuncytochemistry, strong expression of CD151 was found, a protein known to be involved in the stimulation of laminin receptor-associated invasion, and activation of MMPs was also noted, with both observations manifest on the surface of TF and CSCC7 [31-33].

These results denote that the two types of fibroblasts exhibit different actions as regards the proliferation and migration of cancer cells. NFs stimulated cell proliferation whereas TFs promoted migration. Moreover, it was found that the presence of secreted fibroblasts and matrix proteins was fundamental for the survival of tumor cells in primary tissue culture. A similar observation was published by Maffini et al. who showed that only tumor cells injected together with activated fibroblasts are able to colonize in case of mice [34].

It would seem that the differences between NFs and TFs represent the stages of fibroblast transformation from defensive to permissive cells. It can not decidedly be said that the so-called "normal fibroblasts" would indeed represent a defensive cell population. Nevertheless, the fact that they promote cell proliferation suggests that they are on the road to fall into line with supportive mechanisms of cancer. Furthermore, synthesized $\alpha \mathrm{v}$ integrin is able to activate latent TGF- $\beta 1$ alone or by targeting it toward MMPs [35].
Since MMPs facilitate tumor cell invasion and metastasis, in the current study we assessed MMP activities of fibroblasts and tumor cells. Zymography revealed that three MMPs were involved in cervical cancer progression. Fibroblasts, especially TFs, secreted pro-MMP-1, responsible for the digestion of type I and type III collagens, and pro- and active MMP-2 which is implicated in the degradation of the basement membrane. In support of earlier studies, CSCC7 cells produced pro-MMP-7 $[36,37]$. MMP-7, in turn, was found to regulate the angiogenic activity of fibroblasts [38]. Among MMPs. only MMP-2 was present in active form. Direct contact between fibroblasts and tumor cells upregulated the secretion and activation of MMP-2, but only NFs increased TIMP-1 production.

Worldwide, HPV16 and HPV18 contribute to over $70 \%$ of all cervical cancer cases [39], therefore the HPV16 positive CSCC7 tumor cell line was selected for the current study. A number of reports propose that CD151 and integrin $\alpha 6$ have key roles in HPV16 infection of epithelial cells [40-42]. In the current study, although using immunocytochemistry alone, we found strong expression of CD151, both in fibroblasts and cancer cells. This protein is involved in the laminin-binding of various integrin pairs [43] and in the stimulation of laminin receptor-associated invasion, by stabilizing integrins $\alpha 3 \beta 1$ and $\alpha 6 \beta 4$, which is a requirement for motility of invasive tumor cells $[44,45]$. In addition, CD151 is capable of binding and activating MMPs, including pro-MMP-7 onto the cell membrane, facilitating ECM degradation [31-33,46].

We found another molecule, TSP-1, to be critical in the pathology of cervical cancers. TSP-1 is a factor participating in cell adhesion-antiadhesion [47] and is implicated in tumor progression and angiogenesis. It upregulates integrin $\alpha 6$ in keratinocytes and breast cancer cells resulting in an increased level of cell adhesion and tumor cell invasion [48]. Of interest is the rather similar behavior of this molecule in the two types of fibroblasts, which may indicate its perpetual importance in tumor-stromal interaction. We detected $\alpha 4$ and $\beta 1$ integrins on the surface of both types of fibroblasts, an integrin pair known to bind thrombospondin-1 [49]. In this context, this glycoprotein is capable of exerting its actions on the surface of fibroblasts. Earlier reports support the importance of thrombospondin- 1 in the activation of latent TGF- $\beta 1$ as well as in the stimulation of EGFR by its EGFlike domains [50].

The efficient adhesion and directional movements of tumor cells migrating on the surface of a fibroblast layer can be explained by the ordered structure of ECM facilitated by the expression of syndecan- 1 on the surface of fibroblasts [51]. In fact, the presence of syndecan-1 is a typical feature of fibroblasts isolated from cervical cancers 

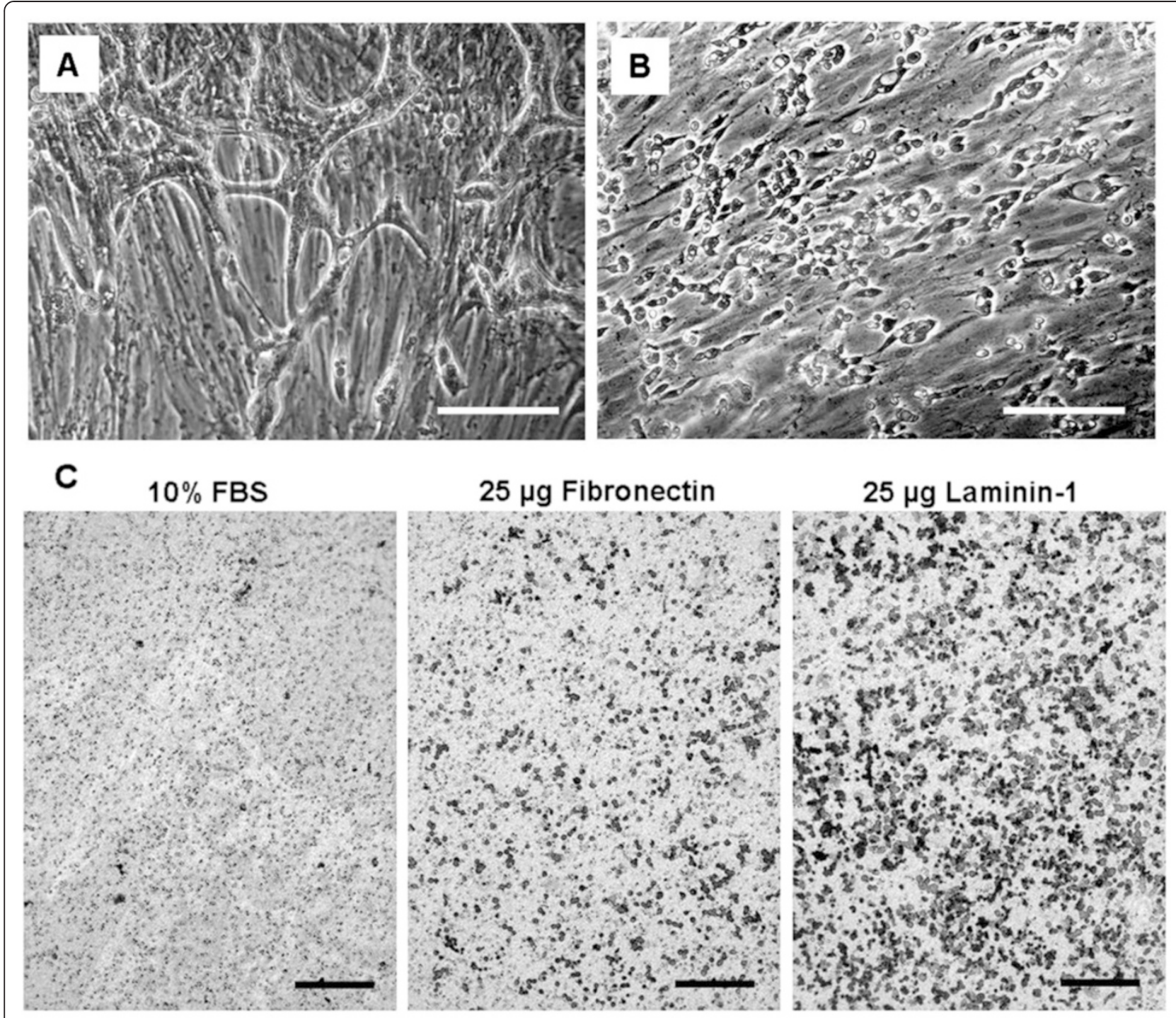

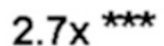

Figure 9 Invasion and migration of tumor cells. Primary (A) and immortalized (B) tumor cells can be seen spread on the fibroblast layer. Tumor cells failed to form groups, preferably dwelling as single cells. Scale bars: $100 \mu \mathrm{m}$. CSCC7 cell migration was moderate for fibronectin and more intense for laminin-1 in a Boyden chamber after 24 hours (C). Scale bars: $200 \mu \mathrm{m}$, stars indicate significance: ${ }^{* *} p<0.001$.

(unpublished result of the authors). Furthermore, migratory phenotype is attributed to the mesenchymal expression of CD44, demonstrated both on NF and TF cell surfaces [52]. Accordingly, we were able to demonstrate that physical contact between fibroblasts and CSCC7 cells initiates tumor cells to start migrating. Soluble CD44, probably shedding due to increased MMP-7 protease activity, promotes the effect further by inhibiting adhesion of tumor cells [53].

\section{Conclusions}

In summary, we were able to demonstrate the differences between NFs and TFs in selectively expressing factors required for proliferation or invasion of cervical cancer cells. The most significant effects of normal fibroblasts when attracted to tumor cells were the production of protein molecules such as TSP-1 promoting antiadhesion, tumor cell proliferation and, together with integrin $\alpha v \beta 3$, the activation of TGF- $\beta 1$ [54]. Thus, MMP-2 was secreted and MMP synthesis was facilitated, resulting in degradation of the basement membrane. At the same time, TFs facilitated laminin-1 synthesis, promoting the migration of tumor cells that expressed laminin receptors. MMP7 produced by tumor cells cleaved to the extracellular domain of CD44, which is a participant in the creation of an anti-adhesive milieu for tumor migration. 


\section{Abbreviations}

SMA: Smooth muscle actin; CSCC7: Cervical squamous cell carcinoma 7; MMPs: Matrix metallo-proteases; TGF- $\beta 1$ : Transforming growth factor beta 1; CAFs: Cancer associated fibroblasts; ECM: Extracellular matrix; HA: Hyaluronan; SCC: Squamous cell carcinoma; EMT: Epithelial mesenchymal transition; HPV: Human papilloma virus; TMA: Tissue microarray; HE: Hematoxylin- and eosin-stained; NF: Normal fibroblast; TF: Fibroblasts derived from a tumorous area; CCMs: Conditioned culture media; CLs: Cell layers; SRB: Sulforhodamine B; SDF-1: Stromal cell-derived factor 1 (CXCL12); TIMPs: Metallopeptidase inhibitors; CD151: Tetraspanin; TSP-1: Thrombospondin 1; EGFR: Epidermal growth factor receptor.

\section{Competing interests}

The authors declare that they have no competing interests.

\section{Authors' contributions}

AF designed and carried out the experiments, analyzed the data and contributed to drafting the manuscript. JD participated in the design of the study and performed the statistical analysis. LO created the primary cell cultures. PH contributed to drafting the manuscript. ZP and GS collected the tissue samples. KK performed the statistical analysis of tissue microarray data. SP performed the confocal microscopy and cell migration assay design. $\mathrm{KB}$ participated in the design of the study and draft of the manuscript. IK conceived the study, participated in its design and coordination and helped to draft the manuscript. All authors read and approved the final manuscript.

\section{Acknowledgement}

This work was supported in part by the Hungarian Scientific Research Fund, grants \#67925 and \#100904 (to IK); grant \#105763 (to KB); and by the Austrian Science Fund, grant FWF P 22287-B13 (to JD).

\section{Author details}

${ }^{1} 1$ st Department of Pathology and Experimental Cancer Research, Semmelweis University, Budapest, Hungary. ${ }^{2}$ Department of Otorhinolaryngology, Medical University Innsbruck, Innsbruck, Austria. ${ }^{3}$ Tumor Progression Research Group, Hungarian Academy of Sciences, Budapest, Hungary. ${ }^{4}$ Maternity Private Department Kútvölgyi Clinical Block, Semmelweis University, Budapest, Hungary. ${ }^{5}$ 2nd Department of Obstetrics and Gynecology, Semmelweis University, Budapest, Hungary. ${ }^{6}$ CRUK/MRC Oxford Institute for Radiation Oncology, Department of Oncology, University of Oxford, Oxford, UK.

\section{Received: 17 November 2014 Accepted: 26 March 2015 Published online: 11 April 2015}

\section{References}

1. Allen M, Louise Jones J. Jekyll and Hyde: the role of the microenvironment on the progression of cancer. J Pathol. 2011;223(2):162-76.

2. Tomakidi P, Mirancea N, Fusenig NE, Herold-Mende C, Bosch FX, Breitkreutz D. Defects of basement membrane and hemidesmosome structure correlate with malignant phenotype and stromal interactions in HaCaT-Ras xenografts. Differentiation. 1999;64(5):263-75.

3. Liotta LA, Kohn EC. The microenvironment of the tumour-host interface. Nature. 2001:411(6835):375-9.

4. Park CC, Bissell MJ, Barcellos-Hoff MH. The influence of the microenvironment on the malignant phenotype. Mol Med Today. 2000;6(8):324-9.

5. Casey TM, Eneman J, Crocker A, White J, Tessitore J, Stanley M, et al. Cancer associated fibroblasts stimulated by transforming growth factor beta1 (TGF-beta 1) increase invasion rate of tumor cells: a population study. Breast Cancer Res Treat. 2008;110(1):39-49.

6. Murphy $G$, Nagase H. Progress in matrix metalloproteinase research. Mol Aspects Med. 2008;29(5):290-308

7. Sato T, Ota T, Watanabe M, Imada K, Nomizu M, Ito A. Identification of an active site of EMMPRIN for the augmentation of matrix metalloproteinase-1 and -3 expression in a co-culture of human uterine cervical carcinoma cells and fibroblasts. Gynecol Oncol. 2009;114(2):337-42.

8. Sato T, Sakai T, Noguchi Y, Takita M, Hirakawa S, Ito A. Tumor-stromal cell contact promotes invasion of human uterine cervical carcinoma cells by augmenting the expression and activation of stromal matrix metalloproteinases. Gynecol Oncol. 2004;92(1):47-56.
9. Karvinen S, Kosma VM, Tammi MI, Tammi R. Hyaluronan, CD44 and versican in epidermal keratinocyte tumours. Br J Dermatol. 2003;148(1):86-94.

10. Hartmann-Petersen S, Tammi RH, Tammi MI, Kosma VM. Depletion of cell surface CD44 in nonmelanoma skin tumours is associated with increased expression of matrix metalloproteinase 7. Br J Dermatol. 2009;160(6):1251-7.

11. Boudreau N, Bissell MJ. Extracellular matrix signaling: integration of form and function in normal and malignant cells. Curr Opin Cell Biol. 1998:10(5):640-6.

12. Niu G, Chen $X$. Why integrin as a primary target for imaging and therapy. Theranostics. 2011:1:30-47.

13. Bachman KE, Park BH. Duel nature of TGF-beta signaling: tumor suppressor vs. tumor promoter. Curr Opin Oncol. 2005;17(1):49-54.

14. Massuto DA, Kneese EC, Johnson GA, Burghardt RC, Hooper RN, Ing NH, et al. Transforming growth factor beta (TGFB) signaling is activated during porcine implantation: proposed role for latency-associated peptide interactions with integrins at the conceptus-maternal interface. Reproduction. 2010;139(2):465-78.

15. Barcellos-Hoff MH, Park C, Wright EG. Radiation and the microenvironment tumorigenesis and therapy. Nat Rev Cancer. 2005;5(11):867-75.

16. Heino J, Ignotz RA, Hemler ME, Crouse C, Massague J. Regulation of cell adhesion receptors by transforming growth factor-beta. Concomitant regulation of integrins that share a common beta 1 subunit. J Biol Chem. 1989:264(1):380-8.

17. Fule T, Csapo Z, Mathe M, Tatrai P, Laszlo V, Papp Z, et al. Prognostic significance of high-risk HPV status in advanced cervical cancers and pelvic lymph nodes. Gynecol Oncol. 2006;100(3):570-8.

18. Hazelbag S, Fleuren GJ, Baelde JJ, Schuuring E, Kenter GG, Gorter A. Cytokine profile of cervical cancer cells. Gynecol Oncol. 2001;83(2):235-43.

19. Baghy K, Dezso K, Laszlo V, Fullar A, Peterfia B, Paku S, et al. Ablation of the decorin gene enhances experimental hepatic fibrosis and impairs hepatic healing in mice. Lab Invest. 2011;91(3):439-51.

20. Fullar A, Kovalszky I, Bitsche M, Romani A, Schartinger VH, Sprinzl GM, et al. Tumor cell and carcinoma-associated fibroblast interaction regulates matrix metalloproteinases and their inhibitors in oral squamous cell carcinoma. Exp Cell Res. 2012;318(13):1517-27.

21. Peterfia B, Fule T, Baghy K, Szabadkai K, Fullar A, Dobos K, et al. Syndecan-1 enhances proliferation, migration and metastasis of HT-1080 cells in cooperation with syndecan-2. PLoS One. 2012;7(6):e39474.

22. Cao XC, Zhang WR, Cao WF, Liu BW, Zhang F, Zhao HM, et al. Aquaporin3 is required for FGF-2-induced migration of human breast cancers. PLoS One. 2013;8(2):e56735

23. Bradford MM. A rapid and sensitive method for the quantitation of microgram quantities of protein utilizing the principle of protein-dye binding. Anal Biochem. 1976;72:248-54.

24. Dudas J, Bitsche M, Schartinger V, Falkeis C, Sprinzl GM, Riechelmann H. Fibroblasts produce brain-derived neurotrophic factor and induce mesenchymal transition of oral tumor cells. Oral Oncol. 2011;47(2):98-103.

25. Arumugam S, Jang YC, Chen-Jensen C, Gibran NS, Isik FF. Temporal activity of plasminogen activators and matrix metalloproteinases during cutaneous wound repair. Surgery. 1999;125(6):587-93.

26. Iozzo RV, Cohen I. Altered proteoglycan gene expression and the tumor stroma. Experientia. 1993;49(5):447-55.

27. Tomasek JJ, Gabbiani G, Hinz B, Chaponnier C, Brown RA. Myofibroblasts and mechano-regulation of connective tissue remodelling. Nat Rev Mol Cell Biol. 2002;3(5):349-63.

28. Imura J, Uchida Y, Nomoto K, Ichikawa K, Tomita S, lijima T, et al. Laminin-5 is a biomarker of invasiveness in cervical adenocarcinoma. Diagn Pathol. 2012;7:105.

29. Horejs CM, Serio A, Purvis A, Gormley AJ, Bertazzo S, Poliniewicz A, et al. Biologically-active laminin-111 fragment that modulates the epithelial-tomesenchymal transition in embryonic stem cells. Proc Natl Acad Sci U S A. 2014;111(16):5908-13.

30. Cress AE, Rabinovitz I, Zhu W, Nagle RB. The alpha 6 beta 1 and alpha 6 beta 4 integrins in human prostate cancer progression. Cancer Metastasis Rev. 1995;14(3):219-28.

31. Yanez-Mo M, Barreiro O, Gonzalo P, Batista A, Megias D, Genis L, et al. MT1-MMP collagenolytic activity is regulated through association with tetraspanin CD151 in primary endothelial cells. Blood. 2008;112(8):3217-26.

32. Sadej R, Grudowska A, Turczyk L, Kordek R, Romanska HM. CD151 in cancer progression and metastasis: a complex scenario. Lab Invest. 2014;94(1):41-51. 
33. Fujita $Y$, Shiomi $T$, Yanagimoto $S$, Matsumoto $H$, Toyama $Y$, Okada $Y$. Tetraspanin CD151 is expressed in osteoarthritic cartilage and is involved in pericellular activation of pro-matrix metalloproteinase 7 in osteoarthritic chondrocytes. Arthritis Rheum. 2006;54(10):3233-43.

34. Maffini MV, Calabro JM, Soto AM, Sonnenschein C. Stromal regulation of neoplastic development: age-dependent normalization of neoplastic mammary cells by mammary stroma. Am J Pathol. 2005;167(5):1405-10.

35. Wipff PJ, Hinz B. Myofibroblasts work best under stress. J Bodyw Mov Ther. 2009;13(2):121-7.

36. Wu SH, Zhang J, Li Y, Li JM. [Expression of ETV5 and MMP-7 in early stage cervical squamous cell carcinoma and its role in lymphatic metastasis]. Ai zheng. 2006;25(3):315-9.

37. Kivi N, Ronty M, Tarkkanen J, Auvinen P, Auvinen E. Cell culture model predicts human disease: Altered expression of junction proteins and matrix metalloproteinases in cervical dysplasia. BMC Clin Pathol. 2012;12:9.

38. Ito TK, Ishii G, Chiba H, Ochiai A. The VEGF angiogenic switch of fibroblasts is regulated by MMP-7 from cancer cells. Oncogene. 2007:26(51):7194-203.

39. Clifford G, Franceschi S, Diaz M, Munoz N, Villa LL. Chapter 3: HPV type-distribution in women with and without cervical neoplastic diseases. Vaccine. 2006;24 Suppl 3:S3/26-34.

40. Abban CY, Meneses PI. Usage of heparan sulfate, integrins, and FAK in HPV16 infection. Virology. 2010;403(1):1-16.

41. Scheffer KD, Gawlitza A, Spoden GA, Zhang XA, Lambert C, Berditchevski F, et al. Tetraspanin CD151 mediates papillomavirus type 16 endocytosis. J Virol. 2013;87(6):3435-46.

42. Aksoy P, Abban CY, Kiyashka E, Qiang W, Meneses PI. HPV16 infection of $\mathrm{HaCaTs}$ is dependent on beta4 integrin, and alpha6 integrin processing. Virology. 2014:449:45-52.

43. Sterk LM, Geuijen CA, van den Berg JG, Claessen N, Weening JJ, Sonnenberg A. Association of the tetraspanin CD151 with the lamininbinding integrins alpha3beta1, alpha6beta1, alpha6beta4 and alpha7beta1 in cells in culture and in vivo. J Cell Sci. 2002;115(Pt 6):1161-73.

44. Nishiuchi R, Sanzen N, Nada S, Sumida Y, Wada Y, Okada M, et al. Potentiation of the ligand-binding activity of integrin alpha3betal via association with tetraspanin CD151. Proc Natl Acad Sci U S A. 2005;102(6):1939-44.

45. Hasegawa M, Furuya M, Kasuya Y, Nishiyama M, Sugiura T, Nikaido T, et al. CD151 dynamics in carcinoma-stroma interaction: integrin expression, adhesion strength and proteolytic activity. Lab Invest. 2007;87(9):882-92.

46. Zoller M. Tetraspanins: push and pull in suppressing and promoting metastasis. Nat Rev Cancer. 2009;9(1):40-55.

47. Bornstein P. Matricellular proteins: an overview. J Cell Commun Signaling. 2009:3(3-4):163-5.

48. John AS, Rothman VL, Tuszynski GP. Thrombospondin-1 (TSP-1) Stimulates Expression of Integrin alpha6 in Human Breast Carcinoma Cells: A Downstream Modulator of TSP-1-Induced Cellular Adhesion. J Oncol. 2010;2010:645376.

49. Decker $\mathrm{S}$, van Valen F, Vischer P. Adhesion of osteosarcoma cells to the 70-kDa core region of thrombospondin-1 is mediated by the alpha 4 beta 1 integrin. Biochem Biophys Res Commun. 2002;293(1):86-92.

50. Sweetwyne MT, Murphy-Ullrich JE. Thrombospondin1 in tissue repair and fibrosis: TGF-beta-dependent and independent mechanisms. Matrix Biol. 2012;31(3):178-86

51. Yang N, Mosher R, Seo S, Beebe D, Friedl A. Syndecan-1 in breast cancer stroma fibroblasts regulates extracellular matrix fiber organization and carcinoma cell motility. Am J Pathol. 2011;178(1):325-35.

52. Spaeth EL, Labaff AM, Toole BP, Klopp A, Andreeff M, Marini FC. Mesenchymal CD44 expression contributes to the acquisition of an activated fibroblast phenotype via TWIST activation in the tumor microenvironment. Cancer Res. 2013;73(17):5347-59.

53. Chetty C, Vanamala SK, Gondi CS, Dinh DH, Gujrati M, Rao JS. MMP-9 induces CD44 cleavage and CD44 mediated cell migration in glioblastoma xenograft cells. Cell Signal. 2012;24(2):549-59.

54. Ludbrook SB, Barry ST, Delves CJ, Horgan CM. The integrin alphavbeta3 is a receptor for the latency-associated peptides of transforming growth factors beta1 and beta3. Biochem J. 2003;369(Pt 2):311-8.

\section{Submit your next manuscript to BioMed Central and take full advantage of:}

- Convenient online submission

- Thorough peer review

- No space constraints or color figure charges

- Immediate publication on acceptance

- Inclusion in PubMed, CAS, Scopus and Google Scholar

- Research which is freely available for redistribution

Submit your manuscript at www.biomedcentral.com/submit 